\title{
Determining the relationship between energy consumption and economic growth in Pakistan
}

\author{
Farhan Ali', Khawar Ahmed Khan', Ali Raza ${ }^{1}$ \\ ${ }^{1}$ Shandong University, Jinan Shandong, China \\ 2Chang'an University, Xian, China
}

E-mail: farhanalivirk@yahoo.com; captainvirk@yahoo.com

Received: 07.10.2019. Accepted: 30.10.2019

\begin{abstract}
Energy is substantial for economic development. This study aims to unveil the causal relationship and long-term association between economic growth and energy consumption in Pakistan. The Granger-Causality test finds that; natural gas consumption, electricity consumption and coal consumption have uni-directional causal relationship with economic growth as (GC, EC and $\mathrm{CC} \rightarrow \mathrm{GDP}$ ), however, GDP growth rate, natural gas consumption and coal consumption unilaterally Granger causes Inflation (GDP, $\mathrm{GC}$ and $\mathrm{CC} \rightarrow \mathrm{CPI}$ ) and lastly coal consumption $\rightarrow$ natural gas consumption $(\mathrm{GC})$, Electricity consumption $(\mathrm{EC}) \rightarrow \mathrm{GC}$. The ARDL estimations delineate natural gas consumption and oil consumption having a positive and negative association with GDP growth rate may have significant long term impacts respectively on the the economic growth of Pakistan.
\end{abstract}

Key words: Oil consumption; Natural gas consumption; Coal consumption; Electricity consumption; CPI; ARDL and Grangercausality test

\section{Introduction}

Economic growth is energy-Intensive phenomenon (Xavier and Baltasar, 2012). The World Bank (2012) pointed out an energy indicator (GDP at US\$/total oil equivalent) as a development stage of a country. Pakistan's average economic growth (2.9\%) remained at bottom during (2009-2013) in comparison to its geographic neighbouring South-Asian countries (India's 6.7\%, Bangladesh's 6.2\% and Sri Lanka's 6.5\%). Energy imbalances (demand-supply gap), internal security matters and natural disasters are among the primary indicators behind the poor economic performance in Pakistan's economy (GOP, 2013) (Figure 1).

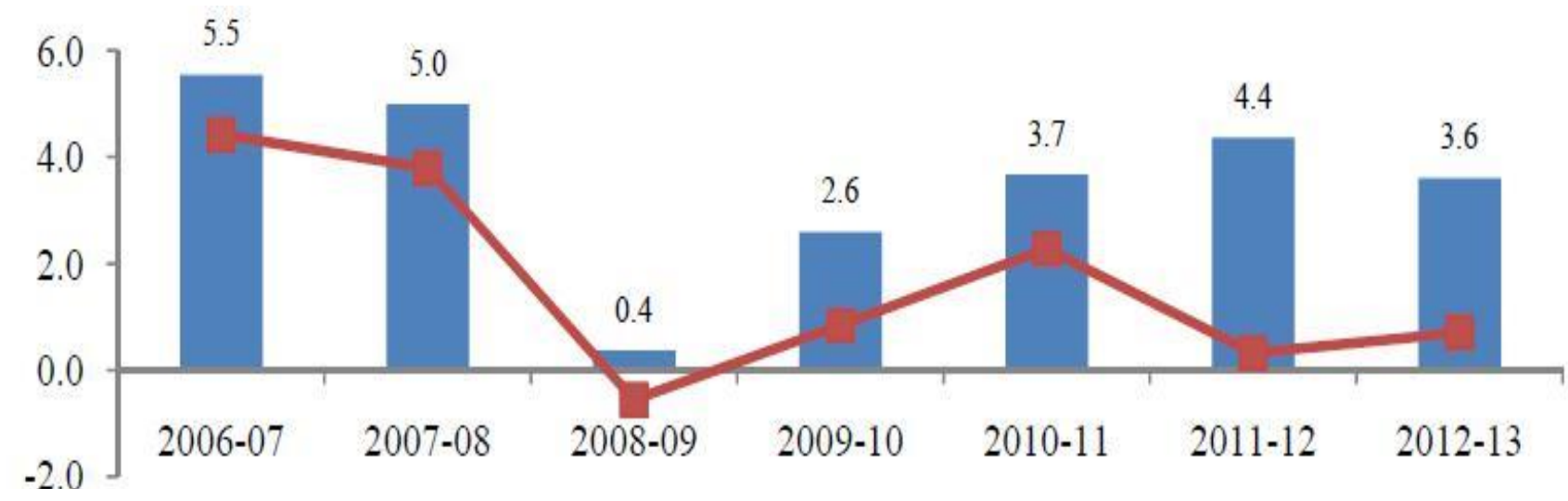

Figure 1. Graphically relationship between economic growth rate and energy consumption in Pakistan [Source. (GOP, 2013)].

Since economic growth and energy consumption having positive association demonstrate lower economic growth rate against lower energy consumption and higher economic growth in case of more energy consumption. Hence, a comprehensive understanding of the linkages of energy consumption and economic growth is increasingly needed as many decision-making courses of actions in developing countries are directly linked to economic growth. This study empirically aims to determine, The causal relationship between economic growth and oil consumption, natural gas consumption, coal consumption and electricity consumption. The shortterm relationship between economic growth and oil consumption, natural gas consumption, coal consumption and electricity consumption. The long-term relationship among economic growth and oil consumption, natural gas consumption, coal consumption and electricity consumption in the presence of Inflation (CPI) as intermittent variable.

\section{Literature Review}

Oil and natural gas as primary fossil fuel energy sources fulfil approx. 60\% of global energy demand (IEA, 2014). Accordingto (GOP, 2013), total energy supply mix (65 million TOE) oil and natural gas are the main contributors having share about $65 \%$ (oil share $=15 \%$ \& gas share $=50 \%$ ) while share of coal is about $7 \%$, and share of nuclear is about $2 \%$ in there GI on Pakistanis one of 
the biggest gas consumers and about proven reserves of coal domestically at 6th position in the world. In comparison to the world Pakistan ranks as 139th (U.S. \$1290.36) with respect to GDP per capita, 12th (0.04) with respect to coal consumption, 100th (440.44 kWh) as coal consumer per capita, and 31st (373000 bbl/d) as crude oil consumer (EIA \& WB, 2011).

According to Hassan and Zaman (2012), the causality between both essential economic dimensions of any economy has many vital implications from theoretical as well as empirical perspective. There are four different views about the causal relationship of Economic Growth and Energy Consumption in the form of such dimensions, 1st that economic growth causally impacts energy consumption of a country i.e.. as an economy grows means economic activities are increasing in the country, so to run these activities there is more requirements of Energy for consumption from different sources of Energy. 2nd view is that Energy Consumption causally impacts Economic growth of a country in such a way that more energy consumption means more economic activities are running in different sectors of an economy which leads to grow up of an economy. 3rd view is that Electricity which is the most convenient form of energy causally impacts Economic Growth of a country and the 4th view point is that both i.e.. economic growth as well as Energy Consumption has no causal relationship.

Among four of the above view-points three are in the favor of that Economic growth and Energy consumption in an economy causes each other but one viewpoint is opposite to the above three. The empirical analysis \& empirical evidence both remained controversial till now. A unidirectional causal relationship from 'EC $\rightarrow E G$ ' indicates that Economic growth of an economy depends upon the Energy Consumed by that economy. It is obvious from here that low energy consumption in an economy will cause low economic growth in response and vice versa (Narayan, P.K., \& Singh, B. 2007, and Odhiambo, N.M. 2009a).

Two way causal relationship between 'EC $\mathrm{EG}^{\prime}$ shows that both Economic Growth \& Energy Consumption are dependent upon each other, i.e. higher economic growth increases energy consumption, higher energy consumption leads to higher economic growth or vice versa. No causal relationship between 'EC \& EG' in any direction indicates that Energy have no impact on each other in an economy (Narayan, P.K., \& Singh, B. 2007, and Odhiambo, N.M. 2009a).

Aqeel and Butt (2001) for Pakistan showed that Electricity Consumption causes Economic Growth, EG causes Oil consumption and Total Energy Consumption. Gosh (2002) for Indian Territory finally explored that 'Electricity Consumption is caused by Economic Growth'. Alam and Butt (2002) in case of Pakistan evidenced two directional causal relationships between 'EG' and 'EC'.

Soytas and Sari (2002) found co integration relationship in G-7 countries. They resulted that in four G-7 countries (Germany, Japan, France \& Italy) run long run unidirectional causal relationship from consumption of Energy to Gross Domestic product but in Korea \& Italy there is unidirectional causal relationship from Gross Domestic Product to Consumption of Energy, in Argentina \& Turkey short run two directional causal relationships exist between GDP as well as consumption of energy.

Paul and Bhattacharya (2004) in India finally traced that, Economic Growth causes Energy Consumption and Energy Consumption also affects Growth i.e. (EG\&EC). Morimoto and Hope (2004) in the case of Sri Lanka found supply of electricity has strong impacts on economicgrowth of Sri Lanka. Low/high Supply of electricity causes low/high economic growth in country, (ES $\rightarrow E G)$.

Yoo (2005) in case of Korea for both periods of time short run \& long run over the data sets of (1970-2002) found that both Economic growth and consumption of electricity both causally impact each other. Liu (2006) in case of China utilized Granger Causality Test \& Error Correction Model on the data set from (1985-2003) to find the causal relationship between GDP and Energy and found unidirectional causal relationship in this way that (GDP $\rightarrow$ Energy). Wang et al. (2006) in the same year for same country utilized Granger Test for the data set consisting of (1953-2002) found No causality between Energy and GDP.

Zou and Chau (2006) in case of China used JJ and Error Correction Model using data set (1953-2002) and found that unidirectional causal relationship between 'EG' Energy as from Energy to GDP. Using data set (1953-1984) they found bidirectional causality. Using (1985-2002) again find two directional causal relationship. Zhao and Fan (2007) for China states that the link of the consumption of energy and growth of the economy does not remain same in different countries/ regions just because of shifting priorities specified to energy along with economic policies during the course of an expansion of economic activities in the country. Zahid (2008) studied the causality between Economic Growth and types of Energy Consumption in case of five South Asian Countries i.e., Pakistan, Sri Lanka, India, Bangladesh \& Nepal. He used ECM \& Toda Yamamoto Technique and finally showed the following conclusion, for Pakistan: Coal $\rightarrow$ GDP, GDP $\rightarrow$ Electricity Consumption \& Total Energy Consumption (unidirectional causality), For Sri Lanka: GDP $\rightarrow$ Electricity Consumption \& Total Energy Consumption, for India: No causality in any direction, for Bangladesh: GDP $\rightarrow$ Electricity Consumption and Natural Gas $\rightarrow$ GDP, for Nepal: Petroleum Consumption $\rightarrow$ GDP.

Yuan et al. (2008) in China by using data set (1963-2005) used JJ and ECM and found two directional causal relationships between economic growth and energy. Odhiambo (2009) conducted a comparative study in three SSA i.e., South Africa (developed country), Kenya and Congo (Low income) to check the causal relationship between Economic Growth and Energy

Consumption by incorporating Prices as intermittent variable. He utilized ARDL-bounds and finally concluded that in case of South Africa \& Kenya there is unidirectional causal relationship running from Energy consumption to Economic Growth (EC $\rightarrow$ EG) but in Congo EG derives EC.

Belke et al. (2010) using data sets from 1981-2007 for 25 OECD Countries studied the causal relationship between Energy Consumption and Economic Growth including Energy Prices. They concluded that, high/low Energy Prices does not decrease/increase in Energy Consumption

(Demand of Energy is inelastic), causality show bidirectional causality between Energy Consumption and Economic Growth.

Alter and Syed (2011) in the case study of Pakistan empirically examined using the data sets (1970-2010) that in short run Electricity is considered as necessity while in long run considered as luxury. Zhang (2011) carried out a study on the world's 3rd largest Energy Consumer Country i.e., (Russia). In the case of Russia, 'EC' and 'EG' has shown bi-directional causal relationship.

Abbas and Choudhury (2012) carried out a causal analysis of Consumption of Electricity and Economic Growth majorly focused agricultural sector of Pakistan and India. According to their causal analysis in case of Pakistan showed that electricity consumption depends upon the growth of agriculture sector, in case of India both agricultural growth rate and consumption of electricity in agriculture sector depend upon each other.

Shahbaz, et al. (2012) investigated the relationship between renewable, non-renewable energy consumption and GDP for Pakistan. Their findings showed that both renewable as well as non renewable energy sources are necessary for energy consumption. Zaman, et al. (2013) conducted a study in case of Pakistan to check the direction of causality between Energy Consumption and different Economic Growth factors of the economy like trade, Education, Growth, environmental, health and population growth factors. They used Co integration \& Granger Causality in this study. The results show that Energy Consumption granger causes positively trade factors, education factors, environmental, health and population growth factors. Wandji (2013) in the case of Cameroon tried to investigate the strength of Energy Consumption relationship to Economic 
Growth. By using co integration 7 Granger Causality, he found that there is unidirectional causality from oil to GDP.

Summarising the available literature in this study about causality between Economic Growth \& Energy Consumption one will reach to the results that from study to study results are not the same but are different \& mixed too. So by reviewing the existing literature this current study investigates the causal relationship between Economic Growth and different types of Energy Consumption in Pakistan and Inflation as CPI as an intermittent variables.

Even though changing climate as a global dilemma of this century, Pakistan's economy still predominantly relies on fossil fuel energy consumption. From the last two decades, Pakistan has been facing severe energy crisis and lower GDP growth in the region. Electricity which is considered as the best form of energy to humans, millions of Pakistanis still do not have electricity security. This study utilises yearly time series data set from 1991-2018. The functional form of our study is as under:

$$
\mathrm{GDP}=\mathrm{f} \text { (Oil consumption, Natural gas consumption, Coal consumption, Electricity Consumption, CPI) }
$$

To incorporate Inflation (CPI) as an intermittent variable is an important factor of this study because Energy Consumption as well as Economic Growth both sides is affected by prices. On one side if prices increase, low energy demand as a result decrease in energy consumption. On the other side if prices increase then decrease in demand and as a result low aggregate output (Table 1 ).

Table 1. Ellipsis used for indicators in this study.

\begin{tabular}{lll}
\hline $\begin{array}{l}\text { Sr. No } \\
1\end{array}$ & $\begin{array}{l}\text { Variables } \\
\text { GDP }\end{array}$ & $\begin{array}{l}\text { Description of Variables (Source of Data) } \\
\text { Gross Domestic Product (as per capita)/i(World iDevelopment indicators, iWDI) } \\
\text { Crude iOil iConsumption (as tons ioil iequivalent iper icapita) i(International iEnergy iAgency, } \\
\text { iIEA) }\end{array}$ \\
2 & OC & $\begin{array}{l}\text { Natural iGas iConsumption (as tons ioil iequivalent iper icapita) i(International iEnergy } \\
\text { iAgency, iIEA) }\end{array}$ \\
4 & NGC & $\begin{array}{l}\text { iConsumption i (as tons ioil iequivalent iper icapita) (International iEnergy iAgency, iIEA) } \\
\text { Electricity iConsumption (as tons ioil iequivalent iper icapita) i(International iEnergy iAgency, } \\
\text { iIEA) } \\
6\end{array}$ \\
\hline
\end{tabular}

\section{Methodology and Modeling}

Granger causality approach is ito forecast current values of one economic variable like Economic Growth by using past values of another economic variable like energy consumption. Following are Granger Causality regression equations required in the present study shown here below, for pair wise Granger causality.

$$
\begin{aligned}
& (\mathrm{GDP}) \mathrm{t}=\alpha_{1}+\sum_{\mathrm{i}=1}^{\mathrm{n}} \beta_{\mathrm{i}}(\mathrm{EC})_{\mathrm{t}-\mathrm{i}}+\sum_{\mathrm{j}=1}^{\mathrm{m}} \gamma_{\mathrm{j}}(\mathrm{GDP})_{\mathrm{t}-\mathrm{j}}+\sum_{\mathrm{k}=1}^{\mathrm{L}} \varphi \mathrm{L}(\mathrm{CPI})_{\mathrm{t}-\mathrm{L}}+\mathrm{e}_{1 \mathrm{t}} \\
& (\mathrm{EC}) \mathrm{t}=\alpha_{2}+\sum_{\mathrm{i}=1}^{\mathrm{n}} \theta_{\mathrm{i}}(\mathrm{GDP})_{\mathrm{t}-\mathrm{i}}+\sum_{\mathrm{j}=1}^{\mathrm{m}} \delta_{\mathrm{j}}(\mathrm{EC})_{\mathrm{t}-\mathrm{j}}+\sum_{\mathrm{k}=1}^{\mathrm{L}} \tilde{\mathrm{nL}}(\mathrm{GDP})_{\mathrm{t}-\mathrm{L}}+\mathrm{e}_{2 \mathrm{t}}
\end{aligned}
$$

Autoregressive Distributed Lag (ARDL) is an empirical approach used to measure empirically the long-term relationship among different variables. If the variables of the study are stationary at different levels like $\mathrm{I}(0) \& \mathrm{I}(1)$ then usually ARDL is utilized to measure long-run relationship among variables which is the second part of the first objective of the present study. ECM (Error Correction Model) utilized to measure empirically short-run relationship among variables included in the present study.

$$
\begin{aligned}
& \Delta(\mathrm{GDP})_{\mathrm{t}}=\alpha+\sum_{\mathrm{i}=1}^{\mathrm{n}} \beta \Delta(\mathrm{GDP})_{\mathrm{t}-1}+\sum_{\mathrm{i}=1}^{\mathrm{n}} \psi \Delta(\mathrm{OC})_{\mathrm{t}-1}+\sum_{\mathrm{i}=1}^{\mathrm{n}} \delta \Delta(\mathrm{GC})_{\mathrm{t}-1}+\sum_{\mathrm{i}=1}^{\mathrm{n}} \eta \Delta(\mathrm{CC})_{\mathrm{t}-1}+\sum_{\mathrm{i}=1}^{\mathrm{n}} v \Delta(\mathrm{EC})_{\mathrm{t}-1} \\
& +\sum_{\mathrm{i}=1}^{\mathrm{n}} \omega \Delta(\mathrm{CPI})_{\mathrm{t}-1}+\lambda_{1}(\mathrm{GDP})_{\mathrm{t}-1}+\lambda_{2}(\mathrm{OC})_{\mathrm{t}-1}+\lambda_{3}(\mathrm{GC})_{\mathrm{t}-1}+\lambda_{4}(\mathrm{CC})_{\mathrm{t}-1}+\lambda_{5}(\mathrm{EC})_{\mathrm{t}-1}+\lambda_{6}(\mathrm{CPI})_{\mathrm{t}-1}+\epsilon_{\mathrm{I}}
\end{aligned}
$$

The parameters being used as coefficients $\beta, \psi, \delta, \eta, v$ and $\omega$ symbolize the short-period relationship among variables and the parameters $\lambda 1, \lambda 2, \lambda 3, \lambda 4, \lambda 5$ i $a$ $\lambda 6$ symbolize the long-term relationship. The null hypothesis (Ho) for bound testing is

Ho: $\lambda \lambda 1=\lambda \lambda 2=\lambda \lambda 3=\lambda \lambda 4=\lambda \lambda 5=\lambda \lambda 6=0$ (There exists no long run relationship among variables)

$\mathrm{H}: \lambda \lambda 1 \neq \lambda \lambda 2 \neq \lambda \lambda 3 \neq \lambda \lambda 4 \neq \lambda \lambda 5 \neq \lambda \lambda 6 \neq 0$ (There exists long run relationship among variables)

Null hypothesis (Ho) suppose that the long run coefficients equal to zero and F-calculated compares with critical bound values presents by Pesaran (1999). If the calculated F statistic is more than the upper bound value then there exists long run relationship among variables, if the calculated $\mathrm{F}$ statistic is less than the lower bound value then there is no co integration (long run relationship) present among variables. If calculated F statistic value falls within lower \& upper bound then it is inconclusive. If it confirms that co-integration exists among the variables then following model for long-run estimation is as:

$$
(\mathrm{GDP})_{\mathrm{t}}=\alpha+\sum_{\mathrm{i}=1}^{\mathrm{n}} \beta(\mathrm{GDP})_{\mathrm{t}-1}+\sum_{\mathrm{i}=1}^{\mathrm{n}} \psi(\mathrm{OC})_{\mathrm{t}-1}+\sum_{\mathrm{i}=1}^{\mathrm{n}} \delta(\mathrm{GC})_{\mathrm{t}-1}+\sum_{\mathrm{i}=1}^{\mathrm{n}} \eta(\mathrm{EC})_{\mathrm{t}-1}+\sum_{\mathrm{i}=1}^{\mathrm{n}} \mathrm{v}(\mathrm{CC})_{\mathrm{t}-1}+\sum_{\mathrm{i}=1}^{\mathrm{n}} \omega(\mathrm{CPI})_{\mathrm{t}-1}+\epsilon_{\mathrm{I}}
$$

Following ECM equation is for estimating short-term relationship among variables:

$$
\begin{gathered}
\Delta(\mathrm{GDP})_{\mathrm{t}}=\Omega+\sum_{\mathrm{i}=1}^{\mathrm{n}} L \Delta(\mathrm{ECM})_{\mathrm{t}-1}+\sum_{\mathrm{i}=1}^{\mathrm{n}} \alpha \Delta(\mathrm{GDP})_{\mathrm{t}-1}+\sum_{\mathrm{i}=1}^{\mathrm{n}} \psi \Delta(\mathrm{OC})_{\mathrm{t}-1} \\
+\sum_{\mathrm{i}=1}^{\mathrm{n}} \delta \Delta(\mathrm{GC})_{\mathrm{t}-1} \sum_{\mathrm{i}=1}^{\mathrm{n}} \eta \Delta(\mathrm{EC})_{\mathrm{t}-1} \sum_{\mathrm{i}=1}^{\mathrm{n}} v \Delta(\mathrm{CC})_{\mathrm{t}-1}+\sum_{\mathrm{i}=1}^{\mathrm{n}} \omega \Delta(\mathrm{CPI})_{\mathrm{t}-1}+\epsilon_{\mathrm{I}} \\
\quad \text { Ukrainian Journal of Ecology, 9(3), } 2019
\end{gathered}
$$




\section{Empirical Estimations and Discussion}

To avoid the spurious-3 results first, we apply the unit root test to check the stationary of the variables. The unit root test results of energy consumption variables indicating their stationarity at the level and unit root test results of GDP and CPI at first difference rules out the chances of spurious results. Results of tables of unit root tests have not shown here will be available on request are given below (Table 2).

Table 2. Estimations of Granger causality test and ARDL (Autoregressive Distributed Lag).

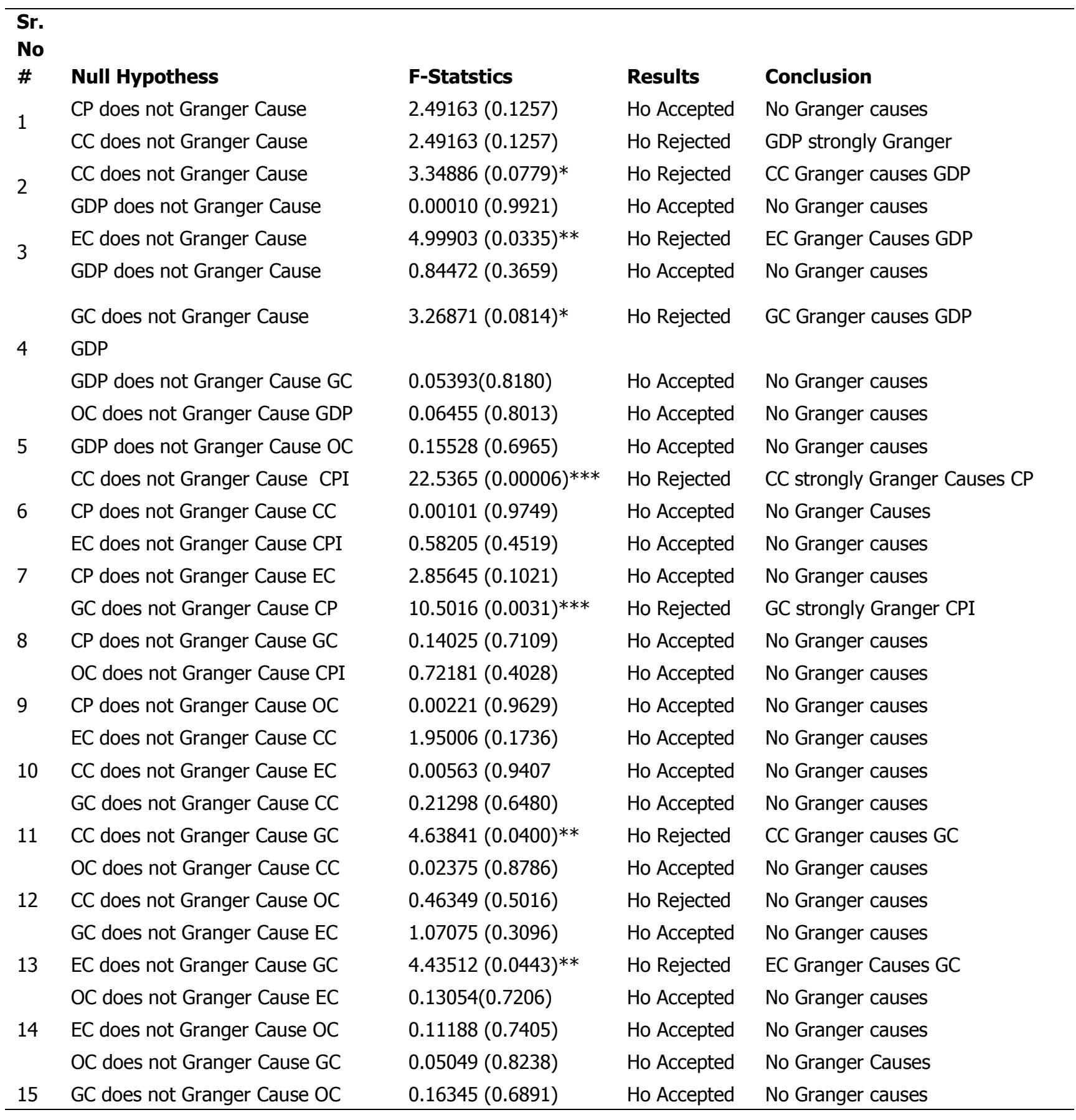

${ }^{3}$ Spurious results meaning that two unrelated series of data indicate high $\mathrm{R}_{2}$ and significant t-statistic which is not valid in reality and none researcher needs it (misleading results); ${ }^{4 * * * * * *}$ shows significant at $1 \% 5 \% \& 10 \%$ level respectively.

Table 2 shows the Granger Causality Results in case of Pakistan, the results indicate that GDP (Gross Domestic Product) strongly causes to CPI (Consumer Price Index) unidirectional as (GDP $\rightarrow$ CPI) at $1 \%$ significance level. Any change in GDP shall bring significant change in CPI in Pakistan. Coal Consumption causes GDP in unidirectional (CC $\rightarrow$ GDP) at $10 \%$ significance level. Electricity Consumption causes in unidirectional to GDP (EC $\rightarrow \mathrm{GDP})$ at $5 \%$ significance level. Gas consumption causes GDP $(\mathrm{GC} \rightarrow \mathrm{GDP})$ in unidirectional at $10 \%$ level of significance. The above table shows that, Coal consumption strongly causes CPI $(\mathrm{CC} \rightarrow \mathrm{CPI})$ at $1 \%$ significance level. Gas consumption strongly causes CPI in unidirectional (GC $\rightarrow$ CPI) at $1 \%$ level of significance. Coal consumption causes Gas consumption $(\mathrm{CC} \rightarrow \mathrm{GC})$ at $5 \%$ level of significance and Electricity consumption causes Gas consumption as, $(E C \rightarrow G C)$ at $5 \%$ level of significance. Before estimating Long-run and short-run relationship among different variables using ARDL \& ECM, F-Test Statistic is calculated. F-Value is compared with the lower I (0) and upper bound I value in the Pesaran et al. study. If calculated F-Statistics value is greater than the upper bound value then it's meaningful to calculate relationship among variables through ARDL and ECM. 


\section{Hypothesis Testing}

H0: $\beta 1=\beta 2=\beta 3=\beta 4=\beta 5=\beta 6=0$ (there exists no long run relationship among variables)

$H 1: \beta 1=\beta 2=\beta 3=\beta 4=\beta 5=\beta 6 \neq 0$ (there exists long run relationship among variables)

After applying the bound F-test, following result was attained.

Table 3. Results of bound F-testing.

\section{Critical values at $\mathbf{5 \%}$ level of significance Lower bound $\mathrm{I}(0)$ \\ 3.12 \\ Upper bound I(1) \\ 4.25}

\section{F-calculated}

4.822548

Table 3 illustrates that I $(0)=3.12$ and I (1)=4.25 at 5\% level of significance presented by Pesaran et al. (2001) bounds table. FCalculated value $=4.822548$ is greater than the upper bound I (1) by using unrestricted trend as well as unrestricted intercept. Greater value of F-Statistics than Upper Bound I (1) indicates to reject Null Hypothesis (Ho) and accept Alternative Hypothesis (H1).

Table 4. Long run coefficients by using the ARDL approach, Dependent Variable: GDP.

\begin{tabular}{llll}
\hline Regressors & Coeffcient & Standard Error & T-Ratio (Prob.) \\
CP & $2.1733^{* * *}$ & 0.62769 & $3.4624(.002)$ \\
OC & $-4968.1^{* * *}$ & 1351.8 & $-3.6751(.001)$ \\
GC & $4360.8^{* *}$ & 1597.5 & $2.7298(.012)$ \\
EC & 9140.9 & 7845.5 & $1.1651(.256)$ \\
CC & -6913.1 & 6678.1 & $-1.0352(.312)$ \\
C & $198.8935^{* *}$ & 86.3678 & $2.3029(.031)$ \\
\hline
\end{tabular}

Table 4 shows the long run estimates for Pakistan calculated using ARDL through Micro fit. In result table, three indicators showed significant impact, two indicators showed insignificant impact.

Consumer Price Index (CPI) is significant at $1 \%$ level of significance. Consumer Price Index has long run positive relation with Gross Domestic Product (GDP). CPI coefficient=2.1733 indicates that one unit increase in CPI causes about 2 unit (dollars) increase in GDP per capita. Increasing price level in Pak causes to increase GDP per capita of the country. Increase in CPI in a country encourages investment in the country. The businessmen invest more to earn more profit. So, increased investment in a country leads to increase the GDP of the country. Oil Consumption (OC) is significant at $1 \%$ level of significance. Oil Consumption in Pakistan has long run negative relationship with Gross Domestic Product (GDP). Oil Consumption Coefficient -4968.1 indicates that one unit (tons oil equivalent) increase (decrease) in consumption per capita of imported oil causes about 4968 unit (dollars) decrease (increase) in GDP per capita. Gas Consumption (GC) is significant at 5\% level of significance. Gas Consumption in Pakistan has long run positive relationship with Gross Domestic Product (GDP). Gas Consumption Coefficient $=4360.8$ indicates that one unit (tons oil equivalent) increase in gas consumption per capita in Pakistan causes about 4361 unit (dollars) increase in GDP per capita of Pakistan or vice versa (Table 5).

Table 5. Error correction representation for the selected ARDL Model. Dependent Variable: DGDP.

\begin{tabular}{llll}
\hline Regressors & Coefficent & Standard Error & T-Ratio (Prob.) \\
DCPI & $1.3549 * *$ & 0.59376 & $2.2818(.032)$ \\
DOC & 1020.8 & 1524.3 & $.66970(.509)$ \\
DGC & $2718.6 * * *$ & 923.6054 & $2.9434(.007)$ \\
DEC & -4676.7 & 4959 & $-.94307(.355)$ \\
DCC & -4309.7 & 3792.4 & $-1.1364(.267)$ \\
DC & 123.993 & 64.118 & $1.9338(.065)$ \\
ECM $(-1)$ & $-.62341 * * *$ & 0.14045 & $-4.4388(.000)$ \\
\hline R-Squared -0.743 & R-Bar-Squared - -0.64954 & \\
F-stat. F $(6,24)[10.6004(.000)] \quad$ DW- statistic & -2.1222 &
\end{tabular}

ECM is usually utilized to know the speed of adjustment of the economy and short run relationship among the indicators of the study. The Error correction Term is significant at $1 \%$ level of significance. $E C M(-1)=-0.62341$ shows that from short run to long run economy converges to the equilibrium at $\sim 62 \%$ per annum with a change in consumer price index (CPI), Oil consumption (OC), Gas consumption (GC), Electricity consumption (EC) and Coal consumption (CC). $\mathrm{R}^{2}=0.74300(74.300 \%)$ shows that about $74 \%$ variation in GDP is explained by Consumer price index (CPI), Oil consumption (OC), Gas consumption (GC), Electricity consumption (EC) and Coal consumption (CC). F-statistics $=10.6004$ shows that overall model is significant. Durbin Watson (DWstatistic) $=2.1222$, shows no serial correlation problem in the model. 


\section{Conclusion}

Energy Security is the main objective of any country's energy policy to have economic efficiency as well as environmental safeguards. An important matter of concern regarding energy is not only need of high production of energy but also an efficient use of the available energy is one of the most important matters of concern now especially in developing countries. Use of renewable energy sources in place of non-renewable energy sources is necessary for Energy Security. If use of non-renewable energy sources continues then available energy will not be clean and harmful to environment as well as human life on the earth. Share of renewable energy to world's power sector was about $21 \%$ in the year 2011 , during the same period of time share of hydroelectric power generation was about $16 \%$ and share of other renewable generation only 5-6\% (WEC, 2013). Everything from edification, to access to resources to strategy and cultural standards of particular places influences perception and understanding of energy security. The World Bank Group (2005), for example, enlightens that energy security is based on the three pillars of energy competence, diversification of energy supply and minimization of price unpredictability. Consumer advocates and users likely to view energy security as rationally priced energy services with no distraction. Key oil and gas producer countries focus on the steadiness of their access to new reserves, while electric utility companies emphasize the integrity of the electricity grid. Politicians dwell on protecting energy resources and infrastructure from terrorism and war. From a distinct vantage point, scientists, engineers, and entrepreneurs characterize energy security as a function of strong energy R\&D, innovation, and technology-transfer systems. These diffuse conceptions of energy security map onto distinct national energy-security concerns, which undoubtedly are reflected in the attitudes of citizens (Janelle et al., 2013).

\section{References}

Abbas, F., Choudhury, N. (2013). Electricity consumption-economic growth Nexus: aggregated and disaggregated causality analysis in India and Pakistan. Journal of Policy, Modeling. 35: 538-553.

Alam, S., Butt, M.S. (2002). Causality between Energy and Economic Growth in Pakistan: An application of cointegration and ECM techniques. Pacific and Asia Journal of Energy. 12(2): 151-165.

Aqeel, A., Butt, M. S. (2001). The relationship between energy consumption and economic growth in Pakistan. Asia-Pacific Development Journal. 8(2): 101-109.

Belke, A., Dobnik, F., Dreger, C. (2010), Energy consumption and economic growth: new insights into the co integration relationship. Energy Economics;doi:10.1016/j.eneco.2011.02.005, in press.

EEA. (2004). Energy subsidies in European Union: A brief Overview. Copenhagen: EEA.

EIA (2014). U.S. Energy Information Administration, Report India.

EIA. (2011). U.S. Energy Information Administration, Editor. Energy Information Administration country profiles. Available from: http://tonto.eia.doe.gov; 1 March 2011.

EIA., WB. (2011). Energy Information Administration and World Bank.

GOP. (2011/12). Government of Pakistan, Economic Survey of Pakistan.

GOP. (2013). Government of Pakistan, Economic Survey of Pakistan and Hydrocarbon Development Institute of Pakistan.

Gosh, S. (2002). Electricity consumption and economic growth in India. Energy Policy. 30: 125-130.

Gujarati D.N., Sangeetha. (2007). Basic Econometrics. Fourth Edition. Tata McGraw Hill Publishing Company Ltd. New Delhi.

Gujarati, D. N. (1995) Basic Econometrics. (Chapters 17, 21 and 22), (3rd edn). New York: McGraw Hill, International Edition, USA. Hassan, Syeda, A., Khalid, Z. (2012). Effect of oil prices on trade balance: New insights into the co integration relationship from Pakistan. Economic Modeling. 29: 2125-2143.

IEA. (2008). International Energy Agency, Energy Statistics-Energy Indicators for World, 2008.

IEA. (2009). International Energy Agency. Global Fossil Fuels Subsidies and their Impacts on Removal. Paris: OECD; 2009.

IEA. (2009). Petroleum Prices, Taxation and Susidies in India. Paris: OECD; June 2009.

IEA. (2014). International Energy Agency (IEA) Publications.

Janelle Knox-Hayes., Marilyn A., Brown., Benjamin, K., Sovacool., Yu, Wang. (2013). Understanding attitudes toward Energy Security: Results of a cross-national survey. Georgia Tech., Ivan Allen College School of public policy. working paper series, 74.

Liu, Xu. Em. Ei. (2006). Explaining the Relationship between $\mathrm{CO}_{2}$ Emissions and National Income: The Role of Energy Consumption. Economics Lettres. 87: 325-328.

Morimoto K., Hope C. (2004). Impacts of electricity supply on economic growth in Sri Lanka. Energy Economics. 26: 77-85.

Narayan, P. K., Prasad, A. (2008). Electricity consumption-real GDP causality nexus: evidance from bootstrapped causality test for 30 OECD countries. Energy Policy. 36: 910-918.

Narayan P. K., Singh, B., Odhiambo, N.M. (2009 a). The electricity consumption and GDP nexus for Fiji Island. Energy Economics 29, 1141-1150. Energy consumption in Tanzania: An ARDL boundstesting approach, Energy policy. 37: 2.

Narayan, P. K., Singh, B. (2007). The electricity consumption and GDP nexus for Fiji Island. Energy Economics. 29: 1141-1150.

Narayan, P. K., Smith, R. (2005). Electricity Consumption, employment and real income in Australia: Evidance from multivariate Granger causality tests. Energy Policy. 33: 1109-1116.

Odhiambo, N. M. (2009b). Energy Consumption and Economic Growth in Africa: A Trivariate Causality Test. Energy Economics. 31: $635-640$.

Odhiambo, N. M. (2009a). Energy Consumption and Economic growth in Tanzania: an ARDL bounds testing approach. Energy Policy 37: 2.

OECD/IEA. (2008). Worldwide trends in energy use and efficiency-key insights from IEA indicator analysis.

Paul, S., Bhattcharya, R. N. (2004). Causality between energy consumption and economic growth in India: a note on conflicting results. Energy Economics 26: 977-983.

Pesaran, M. H., Shin, Y. (1995). Long-run Structural Modeling. DAE Working Paper No. 9419, Department of Applied Economics, University of Cambridge, Cambridge.

Pesaran, M. H., Pesaran, B. (1997). Working with Micro fit 4.0: An Interactive Approach.Oxford: Oxford University Press.

Pesaran, M. H., Shin, Y., Smith, R.J. (2001). Bounds testing approach to the analysis of level relationships. Journal of Applied Econometrics. 16: 289-326.

SBP. (2010-11). Annual Report, The State of Pakistan's Economy, State Bank of Pakistan. 
Shahbaz, M, Lean, H. H., Farooq, A. (2013). Natural gas consumption and economic growth in Pakistan. Renewable and Sustainable Energy Reviews. 18(2): 87-94

Shahbaz, M., Zeshan, M., Afza, T. (2012). Is energy consumption effective to spur economic growth in Pakistan? New evidence from bounds test from level relationship and Granger causality tests. Econ Model. 29: 2310-2319.

Soytas, U., Sari, R. (2002). Energy consumption and GDP: Causality in G-7 countries and emerging markets. Energy Economics. 25: $1-118$.

Toda, H. Y., Yamamoto, T. (1995). Statistical Inference in Vector autoregressions with possibly integrated process. Journal of Econometrics. 66: 225-250.

Wang, S., Yu, L, Lai, K. K. (2006). Forecasting Crude Oil Price with EMD-based Neral Network Esemble Learning Paradigm. Energy Econ. 30: 2623-2635.

WDI. (2011). World Development Indicators.

WDI. (2005). World Development Indicators, CD-ROM. Washington: The World Bank.

WEC. (2009). World Energy and Climate Policy: 2009 Assessment, World Energy Council Publication.

WEC. (2013). World Energy Council for Sustainable Energy. World Energy Resources, 2013 Survey.

Labandeira, X., and Baltasar, M. (2012) Some Economic Aspects of Energy Security. Working Paper 09/2012."

Yoo, S. (2005). The Relationship between Electricity Consumption and Economic Growth in ASEAN Countries. Energy Policy. 34: 3573-3582.

Yris, D. Fondja, W. (2013). Energy consumption and economic growth: Evidence from Cameroon. Energy Policy. (61): 1295-1304. Yuan, J., Kang, J., Zhao, C., Hu, Z., (2008). Energy consumption and economic growth: evidence from China at both aggregated and disaggregated levels. Energy Economics. (30): 3077-3094.

Zahid, Asghar, (2008). Energy-GDP Relationship: A Causal Analysis for the five countries of South Asia. Applied Econometrics and International Development. 8-1

Zaman, K., Khan, M. M., Ahmad, M. (2013). Factors affecting commercial energy consumption in Pakistan: progress in energy. Renew Sustain Energy Rev 2012. 19(3): $107 e 35$.

Zhang, Y. (2011). Study on causality between coal consumption and economic growth in China. Resource and industries. 9: 79-82.

Zhao, J., Fan, J. (2007). Empirical research on the inherent relationship between economic growth and energy consumption in China. Economic Research. (8): 31-42

Zou, G., Chau, K. W. (2006). Short and long-run effects between oil consumption and economic growth in China. Energy Policy. (34): $3644-3655$.

\section{Citation:}

Farhan, A., Khawar, A. K., Ali, R. (2019) Determining the Relationship between Energy Consumption and Economic Growth in Pakistan. Ukrainian Journal of Ecology, 9(3), 322-328.

(cc) $\mathrm{EY}$ This work is licensed under a Creative Commons Attribution 4.0. License 